\title{
De onbegrensde malaise van Australisch asielbeleid
}

Patrick van Berlo

De algehele malaise was kenbaar, zichtbaar, haast tastbaar bij alle drie de jongens die tegenover me zaten in het immigratiedetentiecentrum in Sydney. Ze waren nauwelijks ouder dan ik, althans, in fysieke zin. Geestelijk gezien waren ze oud en versleten, en de doffe uitdrukking in hun ogen maakte dat eens te meer duidelijk. Tegenover me zaten drie schimmen, die knabbelend op een pistachenootje de dag aan zich voorbij zagen trekken.

M., die het meest links zat, vertelde over zijn familie in Syrië, over hoe het land uiteen was gevallen en over hoe de anarchie zich langzaam maar zeker had verspreid als een alles doordringende olievlek. Een gedeelte van zijn familie was in Libanon en een gedeelte was in Qatar. Hij had de Australische autoriteiten gevraagd of hij terug mocht gaan naar Syrië, maar dat mocht niet omdat het te gevaarlijk werd geacht. Hij mocht ook niet naar Libanon, of naar Qatar, en zat dus gevangen aan de andere kant van de wereld. Letterlijk en figuurlijk.

Om het gesprek op een wat luchtiger onderwerp te laten komen vroeg ik of hij een vriendin had. Hij glimlachte, zei dat hij was getrouwd, en voegde toe dat hij twee kinderen had: een zoontje van 6 en een dochtertje van 4. Of ik ook getrouwd was? En had ik ook al kinderen? Ik glimlachte terug en schudde van nee. Ik vertelde hem dat het in Nederland niet gebruikelijk is om op vroege leeftijd te trouwen, en dat we vaak ook een tijdje wachten voor we kinderen krijgen. Gefascineerd door het feit dat zijn kinderen 6 en 4 jaar oud waren, ondanks het feit dat hij mijn leeftijd heeft, vroeg ik hem waar zijn vrouw en kinderen nu waren. Libanon? Syrië?

Zijn glimlach bleef, maar zijn lach werd wranger toen hij zei: 'They are finished.' Ik begreep het niet direct, maar toen het kwartje viel werd ik stil en stotterde ik dat ik dat niet wist en dat het me speet. Hij bleef glimlachen terwijl hij zei dat het niet uitmaakte. Hij maakte het elke dag mee, en iedereen in Syrië had minstens tien van zulke verhalen. 'Mijn moederland is dood', voegde hij eraan toe, waarna hij een tweede pistachenootje openbrak zonder de eerste te hebben opgegeten.

Mijn gesprek met H. was van kortere duur, hij wilde kennelijk niet over zijn situatie praten. Hij hield zich afwezig en beperkte zijn antwoorden tot het minimum aantal woorden dat vereist was om een heldere zin te vormen. Tot hij begon te vertellen over Indonesië en over hoe zijn vrouw, twee kinderen en broer waren omgekomen toen hun bootje op de klippen liep. Eén zoontje had het gered, en hij wees naar een kind dat in zijn eentje verstoppertje speelde onder een tafel. Het kind keek schichtig om zich heen en nam alle aanwezigen nauwlettend in zich op. Van een vrijwilliger hoorde ik later dat het kind al jaren bij een psychiater liep en met allerlei klachten kampte, zowel lichamelijk als geestelijk. Ik huiverde bij de gedachte. 
K. vertelde me misschien wel het meest verbazingwekkende verhaal van de dag. Niet alleen vanwege de inhoud ervan, maar ook omdat hij het me in het Nederlands vertelde. Inderdaad, hij sprak vloeiend Nederlands met een lichte harde g, en vertelde me dat hij was opgegroeid in Gorinchem waar hij naar school was gegaan en uiteindelijk een baan had gevonden. Toen ik hem vroeg hoe hij in hemelsnaam in een Australisch asielzoekerscentrum terecht was gekomen, vertelde hij me over hoe hij op driejarige leeftijd uit Irak was gevlucht en naar Nederland was gekomen, waar hem asiel werd verleend. Hij vertelde hoe zijn vader terug had gemoeten naar Irak en hoe hij zijn moeder, die aan kanker leed en op sterven lag in Bagdad, had bezocht toen hij 18 was. Toen hij echter terug wilde gaan naar Nederland, werd hem de toegang ontzegd omdat hij nooit een verblijfsvergunning had angevraagd. Hij zat vast in een land waar hij de taal niet goed sprak en waar hij de opvattingen niet deelde, als niet-moslim zijnde polderjongen. Hij vertelde hoe moeilijk het voor hem was, en hoe hij noodgedwongen naar Maleisië was gegaan om werk te vinden. Toen dat niet lukte, had hij geprobeerd naar Australië te komen. Met alle gevolgen van dien.

Ik keek naar de drie jongens. M., met zijn wrange glimlach, H., die zo terughoudend was, en K., met zijn onwaarschijnlijk perfecte Nederlandse accent. Drie unieke personen, drie unieke karakters, en toch gevangen in dezelfde, uitzichtloze realiteit van een Australisch immigratiedetentiecentrum. Een plek die in alles lijkt op een gevangenis, maar die een andere naam draagt en dus buiten het bereik van het strafproces lijkt te vallen.

Ik zal niet ontkennen dat landen te kampen hebben met toenemende immigratiestromen en dat het gelegitimeerd kan zijn dat landen hun grenzen afdwingen. Inderdaad, een sluitend immigratiebeleid is gerechtvaardigd en noodzakelijk in de 21 ste eeuw, waar mobiliteit haar toppunt nog steeds niet bereikt lijkt te hebben. Echter, de harde en ongedifferentieerde realiteit waarmee Australië zijn asielzoekers behandelt lijkt niks meer te maken te hebben met rechtvaardigheid of noodzaak. Het is een onverholen beleidskeuze om te bewerkstelligen dat hele groepen mensen buiten de Australische grenzen vallen, terwijl het hele stelsel van asielrecht juist gebouwd is rond begrippen als individualiteit en rechtsbescherming. Het lijkt er in toenemende mate op dat Australië de bewaking van zijn grenzen als een belangrijkere prioriteit ziet dan de bewaking van zijn internationale asielgerelateerde en mensenrechtenverplichtingen, waarbij het individuele verhaal wordt ondergesneeuwd door een collectieve roep om veiligheid. Met het ironische resultaat dat aan degenen die aangetrokken werden door die veiligheid - en die nergens anders heen kunnen - een veilig thuiskomen wordt ontzegd. Terwijl de Australische bevolking keer op keer te horen krijgt dat de overheid er alles aan doet om de 'soevereine grenzen' te beschermen, kwijnen M., H. en K. langzaam weg in hun radeloze posities.

Uit het oog, uit het hart, lijkt de harde realiteit van het Australische beleid. De humanitaire inslag van het asielrecht lijkt stukje bij beetje te zijn verloren op weg naar een vermeend veiliger Australië, waarbij de grens keer op keer een stukje wordt verlegd. 